\title{
The value of pastoralism in Kenya: Application of total economic value approach
}

\author{
D. M. Nyariki ${ }^{1}$ and D. A. Amwata ${ }^{2,3^{*}}$
}

\begin{abstract}
The value of pastoralism practiced in Kenya is not well appreciated, even though it is said to be enormous. The available statistics tend to underestimate this value from the point of view of its contribution to the local and national economies, due to the inadequacy of data and application of inappropriate valuation methodologies. This study analysed the contribution of pastoralism to Kenya's national economy, using the total economic value (TEV) approach and by considering the traditional and non-traditional pastoral values. Secondary data were collected on livestock population, herd composition and structure, honey, beeswax, firewood, fishing and tourism. The findings of this study show that Kenya's pastoral sector has an economic worth of US\$1.13 billion with the livestock sector and non-livestock sector accounting for 92\% (US\$1.04 billion) and 8\% (US\$0.0903 billion), respectively. The annual national pastoral livestock offtake was valued at US\$0.189 billion, while annual meat offtake was estimated at 154, 968 tonnes, valued at US\$0.389 billion. The national annual meat consumption was estimated at 553,200 tonnes, of which pastoral meat contributed 154,968 tonnes or $28 \%$. The TEV approach integrates the many aspects of economic value contributed by pastoral systems, including market and non-market goods and services that are usually not accounted for. An accurate estimate of the contribution of pastoral production can be instrumental in lobbying for enhanced investment in the pastoral areas to boost environmentally sound development.
\end{abstract}

Keywords: Arid and semi-arid lands, Pastoral economy, Livelihoods, Livestock value chain, economic contribution

\section{Introduction}

About $80 \%$ of Kenya is characterised as arid and semi-arid lands (ASAL) with pastoralism as the main source of livelihood to millions of people residing in these lands (Amwata et al. 2015). There is a general consensus that pastoralism contributes between 10 and $44 \%$ of the gross domestic product (GDP) of African countries with approximately 1.3 billion people benefiting from the livestock value chain (Karaimu 2013). Further, over $75 \%$ of cattle herds in Kenya and $90 \%$ in Tanzania are kept by pastoralists who supply the bulk of meat consumed in those countries (Wakhungu et al. 2014; International Livestock Research Institute (ILRI) 2013). Pastoralism directly supports an estimated 20 million people and produces $80 \%$ of the total annual milk supply in

\footnotetext{
* Correspondence: damwata@gmail.com; damwata@seku.ac.ke

${ }^{2}$ Department of Agricultural Sciences, South Eastern Kenya University, P.O.

Box 170-90200, Kitui, Kenya

${ }^{3}$ School of Hospitality and Tourism, Murang'a Unversity of Technology,

P.O.Box 75-10200, Murang'a, Kenya

Full list of author information is available at the end of the article
}

Ethiopia, provides $90 \%$ of the meat consumed in East Africa, and contributes 19\%, 13\% and 8\% of GDP in Ethiopia, Kenya and Uganda, respectively (Nyariki, 2017). It also contributes close to $60 \%$ of the meat and milk products consumed in West African countries (United Nations Economic Commission for Africa (UNECA) 2016). Despite the role of pastoralism in the local, national and global economies, it faces several setbacks that hinder the realisation of its full potential. These setbacks include misconceptions on pastoralism, climate change, globalisation, urbanisation and undervaluation of the pastoral economy (Amwata et al. 2015).

This paper defines pastoralism as per the Government of Kenya (GoK 2012), where it is defined as both an economic activity and a cultural identity in the ASAL. As an economic activity, pastoralism is a livestock production system which takes advantage of the characteristic instability of rangeland environments, where key resources such as nutrients and water for livestock become available in short- 
lived and largely unpredictable concentrations. On the other hand, as a cultural identity, it plays a critical role in socio-cultural functions including source of prestige, wealth, dowry and settlement of family disputes (Nyariki and Ngugi, 2002). However, this definition of pastoralism needs to embrace a landscape and systems approach to encompass people, livestock and the environment. For example, there are many goods and services that are provided by pastoralism and its landscape that have often been overlooked, namely fish, tourism, input in agriculture, recreation, support and regulatory services. There are enormous numbers of studies on pastoralism in Africa, including Kenya. Most popular press and news articles on pastoralism portray its shortcomings rather than its benefits. In Kenya, 93\% of news articles on pastoralists are about drought and conflict, with about $51 \%$ of these articles presenting pastoralists as the cause of the conflict rather than its victims (Integrated Regional Information Networks (IRIN) 2013). In contrast, in India, 60\% of the articles reviewed portray pastoralists as victims who have lost access to grazing land because of the growth of industrial agriculture (Shanahan 2013), the dominance of more powerful social groups and limits to grazing in forested land (IRIN 2013).

Despite the efforts made to understand and support pastoralism, there is a dearth of knowledge on the economic value of the pastoral systems and their environment, resulting in inadequate policy and institutional support for the systems. The limited recognition of pastoralism as an important partner in economic development has led to the marginalisation of pastoral communities, thereby deepening the severity of poverty in the pastoral areas. The main objective of this paper is therefore to fill information gaps regarding the significance and contribution of pastoralism by providing a better estimate and up-to-date assessment of the total economic value (TEV) of pastoralism in Kenya in terms of methodological review, literature review relevant to TEV and overview of the TEV of pastoralism in Kenya.

\section{A review of total economic valuation of pastoralism}

According to Nyariki (2004), the 'economic contribution' of pastoralism should integrate economic and social systems of a country or community or group of communities. A 'social system' refers to the interdependent relationships between the economic factors of production (land, labour and capital) and non-economic factors including attitudes towards life and work, administrative structures, patterns of kinship and religion, cultural traditions and systems of land tenure. His study defines a 'pastoral economy' as a collection of pastoral activities, mainly management, herding and security that leads to the production of mainly livestock and livestock products for domestic consumption and for the market. In this paper, we define a pastoral economy as a system that integrates economic, social and environmental values associated with livelihoods in the ASAL. These include direct and indirect pastoral livelihoods related to ASAL resources-livestock; wildlife; people; natural products like gum, timber, honey and beeswax; and micro-organisms.

Pastoralism is said to make a significant contribution to Kenya's economy with livestock production accounting for $50 \%$ of agricultural GDP, which is $20-30 \%$ of the total GDP (Nyariki 2004; Fitzgibbon 2012). However, the use of GDP to estimate the value of pastoral livestock is inadequate since it only considers livestock and livestock products that are marketed, ignoring the non-marketed products including the value of livestock in subsistence and socio-cultural values which are core components of pastoralism. In support, Behnke and Muthami (2011) estimated the contribution of ruminant livestock to the national agricultural production in 2011 to be $150 \%$ higher than the previously thought value of Kshs 319 billion (US\$3.8 billion). In Tanzania, it was noted that the value of most of the products coming from the extensive livestock system in 2006 was dominated by agro-pastoralists and pastoralists, comprising about $95 \%$ of the total livestock population and was not reflected in the GDP (Odhiambo 2006). This was attributed to the failure of the national data to distinguish and disaggregate the contribution of pastoralism from other forms of livestock production such as commercial ranching, large-scale farmers, dairy production, pastoralists and smallholders. According to Nyariki (2004), Kenya's pastoral sector was worth Kshs 60 billion (US\$800 million), with the internal trade alone netting about Kshs 6 billion (US\$80 million) a year. He further reported that the monetary value of livestock from the pastoral sector in Kenya was Kshs $60-70$ billion with a 'conservative' total annual marketed value both locally and nationally between Kshs 5 billion and Kshs 8 billion. These estimates focused only on the value of livestock and its related products (traditional values) and excluded the emerging values of pastoralism (non-traditional values).

Total economic value is a tool, originally developed for cost-benefit analysis, to deal with the 'priceless' assets that would otherwise escape standard procedures of appraisal (Krätli 2015). The concept is increasingly being used as a framework for valuing pastoralism (Barbier et al. 1997; Nyariki 2004; Davis 2006; Krätli 2015). Studies using the concept have demonstrated the economic benefits associated with pastoralism, which extend beyond the direct use values to subsistence, non-market values, ecological functions and non-use benefits singly or in combination. In Uganda, TEV of pastoralism has been assessed using the national GDP and export revenue earning (Muhereza and Ossiya 2004), but their assessment fails to capture the cultural, ecological and environmental values. Hesse and 
MacGregor (2006) identified a broad framework for assessing the benefits of pastoralism that looks beyond the immediate benefits of livestock and livestock products. In support, Hatfield and Jonathan (2006) and Mdoe and Mnenwa (2007) acknowledged pastoralism as an integral system with three components: (i) resource stocks or assets, (ii) flow of environmental services and (iii) the attributes of an ecosystem. Further, they elaborated on the values of pastoralism as direct measurable values (live animals, milk, hides and other derivatives), direct unmeasured values (employment, production and environmental management skills), indirect measurable values (subsistence, inputs to tourism, inputs to agriculture, market linkages and taxes) and indirect unmeasured values (ecological and rangeland services, agricultural services, sociocultural values, and option and existence values). On their part, Letara et al. (2006) estimated the economic significance of pastoralism in Tanzania through its nyama choma (grilled meat) sector and its supply chains back to pastoral systems that provide meat that acts as the raw material. Also, Odhiambo (2006) conducted a study on TEV of pastoralism in Kenya, Tanzania, Uganda and Sudan. He alludes to the paucity of data on the economic worth of pastoralism to the national economies due to weak analytical frameworks that quite often give preference to livestock and its related products while ignoring the non-monetised values such as manure, draught power, control of bush and weeds, recycling of household waste and role of pastoralism in conservation and wildlife-based tourism.

Further, Davis (2006) conducted a study on TEV in Kenya. His study focused on the value of pastoralism from livestock and its related products and the emerging goods and services from the pastoral economy and on secondary data at the national level. Krätli (2015) conducted a study on the methodological options and gaps in TEV studies of pastoral systems. He outlined the advantages of TEV as including: gaining knowledge on measuring tools; procedures and what to be measured; on data gaps and on the invaluable assets that cannot be traded for money. However, he further stated that TEV is more concerned with unfolding all avenues or categories of value rather than building of a total figure. Thus, in his opinion, TEV is a tool for putting priceless assets on the map and as a platform of comparison with marketed natural assets for a more balanced representation of value in decision-making. He argues that this brings out the hidden values into the open to help prevent the dangers of oversight in policymaking or taking these values for granted. For example, various studies have estimated the different non-livestock-related pastoral products and services that have option or bequest values such as ecological functions of pastoral landscapes. In support, Davis (2006) and Nyariki (2004) reinforce the need for the public and government ministries to be made aware of the value of pastoral goods and services while they still exist. Although Krätli (2015) stresses that the values derived from the approach of TEV are not additive, many studies have used various approaches and methodologies that show the additive nature of the value of TEV (Nyariki 2004; Mdoe and Mnenwa 2007; and King-Okumu 2016). Therefore, the present study emphasises the additive value of TEV, which is the most understood by policy-makers when investing in any transformation.

\section{Methods}

A desk review and secondary data were used in this study. The desk review involved documenting relevant methodological approaches used by previous studies to carry out an economic analysis of pastoralism in Kenya and other countries in Africa. Secondary data were collected from relevant Government and non-governmental entities at the national level. These include the Kenya National Bureau of Statistics (KNBS); Ministries responsible for agriculture, livestock, fisheries, finance, planning and trade; National Drought Management Authority; statistical abstracts; trade cooperatives and agencies; abattoirs; previous research reports; development project reports; and databases of international and regional organisations such as the Food and Agriculture Organization (FAO), International Food Policy Research Institute (IFPRI), World Bank, and Intergovernmental Climate Prediction and Application Centre (ICPAC). Data were collected on livestock statistics, trade and export of live animals and animal products, honey and wax production, fishing and tourism.

This study focuses both on livestock-related goods and services (traditional) and non-livestock-related goods and services (non-traditional). The values of livestock and its related products provided by pastoralism include those from meat, milk, hides, skins and blood. On the other hand, non-livestock pastoral values refer to those provided by pastoral landscapes or economy such as ecosystem services that are increasingly becoming critical in enhancing pastoral livelihoods such as beekeeping, marginal agriculture, tourism and fishing. In its strict definition, the TEV approach used in this study may be categorised into two broad parts-use values and non-use values. The use values include direct use values, indirect use values and option values. The non-use values include bequest values and existence values that people hold for a pastoral area which are in no way linked to the use of the area. The conceptual framework is presented in Fig. 1.

The extent to which the concept of TEV is applied would depend on the availability of data. Building on the conceptual framework in Fig. 1, data were collected on sales, subsistence, and complementary and supplementary economic activities to pastoralism. These included 


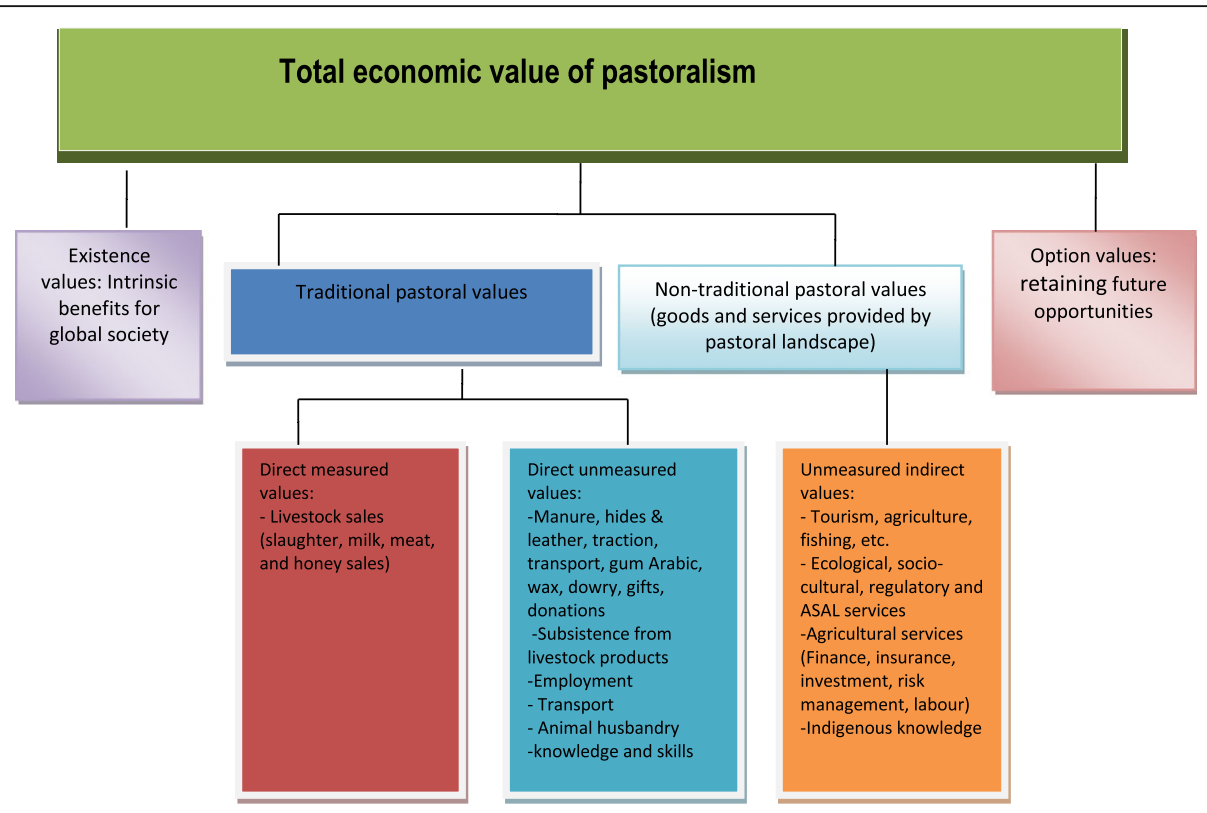

Fig. 1 Conceptual framework for total economic valuation of pastoralism. Source: modified from Hesse and MacGregor 2006 and Davis 2006

national data on sales of livestock and its related products (meat, eggs, milk, hides and manure), national market data, and statistics on GDP and foreign exchange earnings. Subsistence data were related to relevant previous studies. Complementary activities are those that support rather than compete with pastoralism such as beekeeping and, to some small extent, wildlife or tourism, while supplementary activities are operated within the pastoral landscape and may use resources that have option value and are of no immediate use for pastoral production, but may in the long run displace pastoralism, such as to a large extent wildlife-based tourism, fishing and mineral exploration. The complementary, supplementary or competing production to pastoralism may generally be referred to as non-traditional or alternative pastoral production.

Pastoralists have moved from herding a variety of animals as a forage and livestock management strategy, which can be viewed as having economic rationality, to more diversified economic activities to enhance resilience in Kenya (IGAD 2017). This economic diversification is seen as a means of maximising rangeland production. For example, pastoralists have diversified their dietary foods from meat, milk and blood to cereals, chicken and fish. Pastoral fish consumption is an emerging trend, especially in areas around lakes and rivers or during the rainy seasons. Several types of activities such as marginal agriculture and fishing are increasingly being maintained to secure the survival of pastoralists since traditional pastoralism has failed to meet the everchanging demands by the inhabitants of the rangelands. Therefore, the various activities have ecological and economic implications. For instance, the diversification of livestock species, such as browsers and grazers and mixed feeders, ensured that each species uses different ecological niches and has different economic and social values, thus leading to optimisation of resource use. Pastoralists adopt the principle of common use or, in economic parlance, optimum combination of outputs, to improve the efficiency of range use. As in many land-use decisions for which the alternative products have a price (and this need not be monetary as in the 'modern' world, because it may be physical or even non-material), for example, livestock and forage, principles of production economics can be used to explain pastoral decisions. While a pastoralist will not involve himself in complicated computations in relation to the allocation of various uses to maximise output from his fixed resources such as land and, in the short to medium term, labour, it is believed that he generally understands these relationships.

The principle of common use for optimum outputs is illustrated in Fig. 2. As can be observed from the figure, if initially a pastoralist engages in alternative (non-traditional pastoral) production such as bee production, wildlife tourism and fish production, (traditional) pastoral production, which entails livestock production, also increases (section $\mathrm{AB}$ on the plot). This then improves the overall output level of the pastoralists. This depicts a region of complementarity. Thus, if the engagement of alternative products is kept at a reasonable level, it would not adversely affect the main source of livelihood, i.e. livestock production. However, if the production of some of the alternative livelihoods is increased beyond a certain point, then competition with the main 


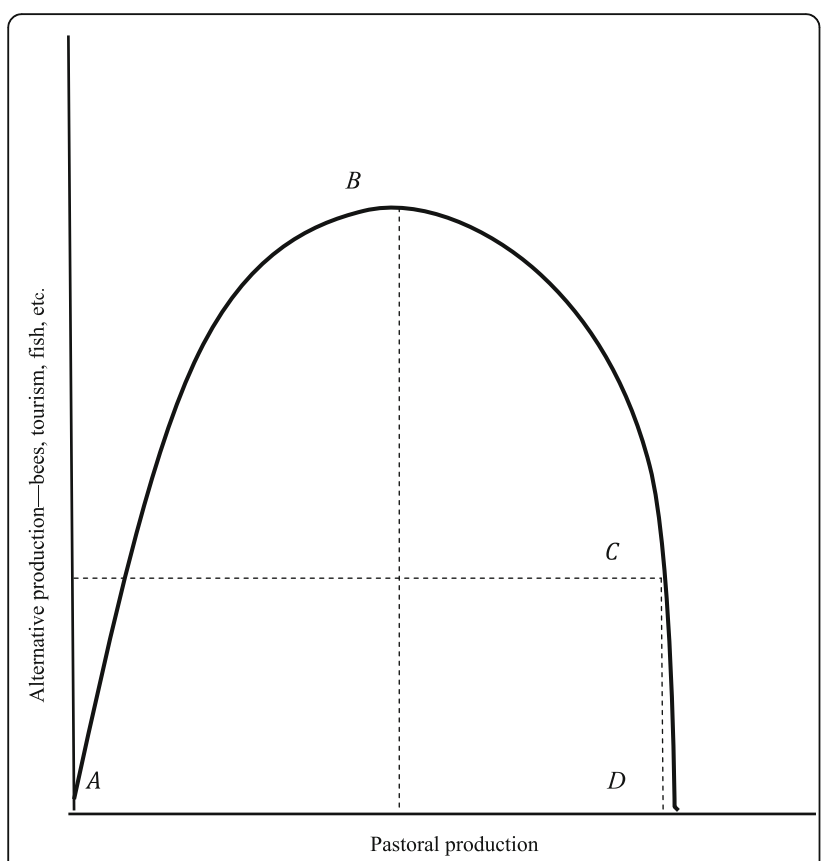

Fig. 2 Complementary, supplementary and competitive production in the use of common pastoral resources

production sets in and the production-possibility curve starts to drop, showing that the overall level of output can only be maintained if there is a reduction in the production of the alternative products (section BC). Finally, $\mathrm{CD}$ shows a situation where, as more and more of the livestock is produced, competition amongst the everincreasing number of livestock for limited rangeland resources causes the production of alternative products to increasingly drop. However, at the maximum point of livestock production, there would be resources that are not used and would go to waste if not utilised to produce alternative products. This can be exemplified by varying levels and a constant level of the production of bees and livestock, respectively, and depicts a supplementary relationship; for example, bee production may not use the resources meant for livestock, at least not at low levels of the former's production.

\section{Results and discussion}

To estimate the economic worth of pastoralism in Kenya, the pastoral values were categorised into traditional and non-traditional. The traditional pastoral values stem from livestock and its related products such as milk, meat, hides and skins, while non-traditional pastoral values include honey, firewood, wax, gum resin, fish and tourism.

\section{Traditional pastoral values Livestock numbers}

The estimation of the economic contribution of livestock and its products depends on accurate livestock numbers. The annual average numbers of Kenya's national livestock by species are presented in Table 1 for the period 2010 to 2015. These numbers form the capital base for livestock products and services and were used to generate the pastoral livestock herd. The proportion of the pastoral herd as a percentage of the national population has been reported by various scholars (Nyariki 2004; Davis 2006; Fitzgibbon 2012). According to Nyariki (2004) and Davis (2006), the proportions of the pastoral herd as a percentage of the national livestock population by species were cattle, $44 \%$; sheep, $57 \%$; goats, $50 \%$; and camels, 100\%. However, Fitzgibbon (2012) reported higher percentages, which were cattle, 70\%; sheep, $87 \%$; goats, 91\%; and camels, $100 \%$. This study chooses the most common estimates used by Nyariki (2004) and Davis (2006) (Table 1).

To estimate the value of the pastoral herd in Kenya, livestock species were standardised into tropical livestock units (TLU) to take into consideration the different classes of livestock. The conversion factors for TLU are as recommended by Mbuza et al. (2014) and Peden et al. (2002) as follows: bull, 1 TLU; cow or heifer, 0.7; calf, 0.3; steer, 0.8; sheep, 0.1; goat, 0.1, camel, 1.1 and chicken, 0.01. A livestock herd structure was established and used to derive the pastoral TLU and their value. Herd structure categorises livestock into different classes based on purpose and nature of production, specifically cows in milk, non-milk cows, bulls, heifers, calves and steers (Mwanyumba et al.

Table 1 National livestock population in relation to pastoral herd in Kenya, 2010-2015

\begin{tabular}{|c|c|c|c|c|c|c|c|c|}
\hline \multirow[t]{2}{*}{ Year } & \multicolumn{2}{|l|}{ Cattle } & \multicolumn{2}{|l|}{ Sheep } & \multicolumn{2}{|l|}{ Goats } & \multicolumn{2}{|l|}{ Camels } \\
\hline & National & Pastoral & National & Pastoral & National & Pastoral & National & Pastoral \\
\hline 2010 & $17,862,852$ & $7,859,655$ & $17,562,104$ & $10,010,399$ & $28,174,158$ & $14,087,079$ & $3,030,600$ & $3,030,600$ \\
\hline 2011 & $18,173,500$ & $7,996,340$ & $17,821,600$ & $10,158,312$ & $28,860,700$ & $14,430,350$ & $3,091,200$ & $3,091,200$ \\
\hline 2012 & $19,129,800$ & $8,417,112$ & $16,115,701$ & $9,185,950$ & $22,181,935$ & $11,090,968$ & $2,864,732$ & $2,864,732$ \\
\hline 2013 & $18,138,500$ & $7,980,940$ & $16,600,911$ & $9,462,519$ & $24,637,393$ & $12,318,697$ & $2,899,244$ & $2,899,244$ \\
\hline 2014 & $17,811,845$ & $7,837,212$ & $17,420,207$ & $9,929,518$ & $25,430,058$ & $12,715,029$ & $2,937,262$ & $2,937,262$ \\
\hline 2015 & $18,223,299$ & $8,018,252$ & $17,104,105$ & $9,747,340$ & $25,856,849$ & $12,928,424$ & $2,964,608$ & $2,964,608$ \\
\hline
\end{tabular}

Source of data: Faostats 
2015). Using the herd structure averages from Nyariki et al. (2009) in Maasai Mara and from Otte and Chilonda (2012) in the pastoral areas of Kenya, the herd structure for the pastoral households was as follows: cows in milk, 17\%; non-milk cows, $23.7 \%$; bulls, $5.5 \%$; steers, $17.9 \%$; and steers/heifers, $19.6 \%$. These figures were used on pastoral herds in Table 1 to generate a pastoral cattle herd structure shown in Table 2.

Using the livestock herd structure in Table 2, the pastoral herd was converted into TLU to standardise the livestock species into a common unit (Table 3) by applying the conversion factors for TLU recommended by Mbuza et al. (2014) and Peden et al. (2002).

Using data from Faostats (2014), Kenya National Bureau of Statistics (2009) and RoK (2016), the average annual pastoral TLU is estimated at 11,683,143 with cattle contributing $50 \%$ of the total pastoral TLU, camels $30 \%$, and goats and sheep $11 \%$ and $8 \%$, respectively. However, chickens contributed negligibly and were not recognised as a sub-component of livestock. To estimate the value of pastoral live animals in Kenya, the total pastoral TLU was multiplied by Kshs 20,000 (US\$200), which is an average price for an animal weighing $250 \mathrm{~kg}$ in the pastoral areas, giving an estimate of Kshs 233.7 billion (US\$2.337 billion).

\section{Pastoral herd offtake}

Offtake may be defined as the removal of live animals or their products from the herd to within the household mainly for consumption, or to outside destinations through gifts, and cultural and religious practices, or markets for sale (Nyariki 2009; King-Okumu et al. 2016). The most important livestock-related offtake is the live form. Davis (2006) and Nyariki (2009) define livestock offtake as the percentage of the current year's herd that is removed through sales, deaths, gifts, home slaughter or theft from the total herd size kept in a year. The forms of livestockrelated offtake include live animals, milk, meat, hides, skins and manure. The rate of livestock offtake from pastoral herds in Kenya has been estimated at 10\% per annum (Davis 2006) compared to that from ranches of 25\% in Ethiopia (Coppock 1994). Nyariki and Munei (1993); (RoK 2000) and Nyariki (2004) reported livestock offtake in the ASAL as cattle, 10\%; camels, 2\%; and sheep and goats, 7\%. However, King-Okumu et al. (2016) reported an increase in rates of livestock offtake in Isiolo County that were cattle, $15 \%$; camels, $1.7 \%$; sheep, $13.2 \%$; and goats, $13.7 \%$. Therefore, this study adopts averages of King-Okumu et al. (2016) and Nyariki (2004) to obtain rates of livestock offtake as $12.5 \%$ for cattle, $1.85 \%$ for camels, $10.1 \%$ for sheep and $10.4 \%$ for goats that are used to estimate the annual rates of livestock offtake.

Taking a 6-year (2010-2015) average, these rates then translate into 731,665 TLU for cattle, 65,814 TLU for camels, 134,456 TLU for goats, 10,724 TLU for sheep and 819 TLU for chickens, which are removed from pastoral herds annually. If values are attached to this offtake, a total annual marketed value both locally and nationally is close to Kshs 18.9 billion. This figure is about 2.4 times the estimate of Kshs 8 billion reported by (RoK 2000) and Nyariki (2004). The explanation for the difference is that livestock prices have since doubled, which could be attributed mainly to inflation and the general rise in commodity prices over time.

In terms of meat supply, if the average offtake in Table 4 and the average carcass weights of livestock as shown in the table are used, the pastoral herds produce in the order of 154,968 tonnes of meat from the various livestock species annually, a figure double the estimate of 71,118 tonnes reported by Nyariki (2004). While the exact amount of what the pastoralists require for their own meat needs is not known as they supplement meat with milk, blood and grains, this figure is much beyond what they consume. Further, Zaal (1998) established that on caloric terms of trade, the equal cash value of meat/ milk and grains gives many times more calories in grains than in milk/meat.

The Government of Kenya (RoK 2010) estimated the annual meat from camels at 7000 tonnes valued at Kshs 2 billion (US\$ 0.02 billion) annually. In 2015, this study estimates the annual meat from camels at 9872 tonnes valued at Kshs 2.47 billion (US\$00247 billion), an increase of Kshs 0.47 billion (US $\$ 0.0047$ billion) in a period of 11 years, which could be attributed to inflation, growing demand for camel meat and improved access to data.

Table 2 Pastoral cattle herd structure

\begin{tabular}{|c|c|c|c|c|c|c|c|}
\hline \multirow[t]{2}{*}{ Year } & \multicolumn{7}{|c|}{ Pastoral cattle by composition, 2010-2015 } \\
\hline & Cattle & Milk cows & Non-milk cows & Bulls & Heifers & Steers & Calves \\
\hline 2010 & $7,859,655$ & $1,336,141$ & $1,862,738$ & 432,281 & $1,540,492$ & $1,406,878$ & $1,281,124$ \\
\hline 2011 & $7,996,340$ & $1,359,378$ & $1,895,133$ & 439,799 & $1,567,283$ & $1,431,345$ & $1,303,403$ \\
\hline 2012 & $8,417,112$ & $1,430,909$ & $1,994,856$ & 462,941 & $1,649,754$ & $1,506,663$ & $1,371,989$ \\
\hline 2013 & $7,980,940$ & $1,356,760$ & $1,891,483$ & 438,952 & $1,564,264$ & $1,428,588$ & $1,300,893$ \\
\hline 2014 & $7,837,212$ & $1,332,326$ & $1,857,419$ & 431,047 & $1,536,094$ & $1,402,861$ & $1,277,466$ \\
\hline 2015 & $8,018,252$ & $1,363,103$ & $1,900,326$ & 441,004 & $1,571,577$ & $1,435,267$ & $1,306,975$ \\
\hline
\end{tabular}


Table 3 Pastoral cattle herd composition in TLU

\begin{tabular}{lllllll}
\hline Year & \multicolumn{6}{l}{ Cattle TLU } \\
\cline { 2 - 7 } & Cows & Bulls & Heifers & Steers & Calves & Total TLU \\
\hline 2010 & $2,640,058$ & 432,281 & $1,155,369$ & $1,125,502$ & 384,337 & $5,737,547$ \\
2011 & $2,685,971$ & 439,799 & $1,175,462$ & $1,145,076$ & 391,021 & $5,837,329$ \\
2012 & $2,827,308$ & 462,941 & $1,237,316$ & $1,205,330$ & 411,597 & $6,144,492$ \\
2013 & $2,680,798$ & 438,952 & $1,173,198$ & $1,142,870$ & 390,268 & $5,826,086$ \\
2014 & $2,632,519$ & 431,047 & $1,152,071$ & $1,122,289$ & 383,240 & $5,721,165$ \\
2015 & $2,693,331$ & 441,004 & $1,178,683$ & $1,148,214$ & 392,093 & $5,853,324$
\end{tabular}

Source: calculated from Faostats data; County Integrated Development Plans (2013)

Using the 2009 population census and a growth rate of $2.9 \%$ per year, the Kenyan human population was estimated at 46.1 million (World Bank 2017). Per capita consumption of meat was estimated at $12 \mathrm{~kg}$ in 2002 (Nyariki 2004). Therefore, the amount of meat consumed annually is about 553,200 tonnes. To this, the pastoral areas contribute about 154,986 tonnes or $28 \%$ of the total national consumption. The rest comes from ranches, 'large farms', smallholders (Fig. 3) and potentially from imports as well as countries such as Somalia, Sudan, Tanzania, Uganda and Ethiopia.

Nyariki et al. (2009) estimate the population of pastoralists at $20 \%$ of the national population. Using the $2015 \mathrm{hu}$ man population estimate of 46.1 million to estimate the current population of pastoralists, we obtain about 9.22 million people that would consume 110,640 tonnes of meat. This implies that out of the total meat offtake from pastoral herds, about $71.7 \%$ is consumed locally while the rest is a surplus which goes to support the rest of the country's population; thus, pastoralists are net meat 'exporters'. At an average producer price of Kshs 250 per kilogramme of meat (RoK 2016), the total amount of money equivalent to 154,968 tonnes of meat is over Kshs 38.7 billion. This is what may be regarded as annual income both in monetary terms and in 'kind' from slaughter. About $18.3 \%$ of this accrues as direct monetary income that goes to meet pastoral household requirements such as clothing, shelter, health, fees and miscellaneous.

\section{Milk production in pastoral systems}

Milk offtake from pastoral herds is rarely quantified compared to slaughter offtake. Therefore, little information is available on this, particularly on commercial offtake. According to government statistics, however, milk production has increased more than twofold. Most of the milk produced comes from large-scale producers and smallholders, while the rest (25\%) comes from the zebu (local breeds) herd-a large number of this coming from the pastoral herds. To calculate the volume of livestock milk production, we used the following rates in relation to herd numbers in the ASAL as identified by Nyariki (2004), Behnke and Muthami (2011) and King-Okumu et al. (2016): cattle-59 L per head; camels-186 L per head, estimating $34 \%$ of the total herd lactating and $547 \mathrm{~L}$ per lactating camel per year; and sheep and goats $-51.2 \mathrm{~L}$ per head, assuming $40 \%$ of the flock are does or adult females, each producing $0.351 \mathrm{~L}$ per day.

Using these estimates, from 2010 to 2015, the average annual national pastoral milk production from cattle is calculated as being 473,076 tonnes, approximately $14.4 \%$ of the national cattle milk, with an estimated value of Kshs 28.4 billion (US\$0.284 billion). Similarly, annual pastoral goat milk is estimated at $15,514,108.80 \mathrm{~L}$, valued at Kshs 0.931 billion (US $\$ 0.00931$ billion, constituting about $23.3 \%$ of the national goat milk. Similarly, the camel milk was estimated by multiplying the population of camel by the milk production per head, i.e. 2,964, $608 \times 186 \mathrm{~L}$; thus, 551.4 million (US\$0.551 million) litres of milk valued at Kshs 16.5 billion (US\$0.165 billion). Also, sheep milk in the pastoral areas is estimated at 3267 tonnes, valued at Kshs 32.7 million (US\$0.327 million) (Table 5). In total, pastoral milk from cattle, sheep, goats and camels constitute about $18 \%$ of the milk produced in the country valued at Kshs 46.2 billion (US $\$ 0.462$ billion).

The above calculations show that pastoral milk contributes about $18 \%$ of the national total milk, which is a decline from a figure of $21.7 \%$ reported by Nyariki (2004). Similarly, the contribution of camel milk to the national total milk production has since decreased to

Table 4 Average annual meat offtake from pastoral herds

\begin{tabular}{llllll}
\hline Species & $\begin{array}{l}\text { Average live } \\
\text { weight }(\mathrm{kg})\end{array}$ & $\begin{array}{l}\text { Average carcass } \\
\text { weight (kg) }\end{array}$ & $\begin{array}{l}\text { Average annual } \\
\text { offtake (TLU) }\end{array}$ & $\begin{array}{l}\text { Average annual } \\
\text { offtake (tonnes) }\end{array}$ & $\begin{array}{l}\text { Value in Kshs } \\
\text { (billion) }\end{array}$ \\
\hline Cattle & 250 & 150 & 731,665 & 109,750 & 27.4 \\
Sheep & 30 & 20 & 10,724 & 1609 & 0.40 \\
Goats & 30 & 20 & 134,456 & 33,614 & 8.40 \\
Camels & 250 & 150 & 65,814 & 9872 & 2.47 \\
Chicken & 1.2 & 0.8 & 819 & 123 & 0.03 \\
& & & & 154,968 & 38.74 \\
\hline
\end{tabular}




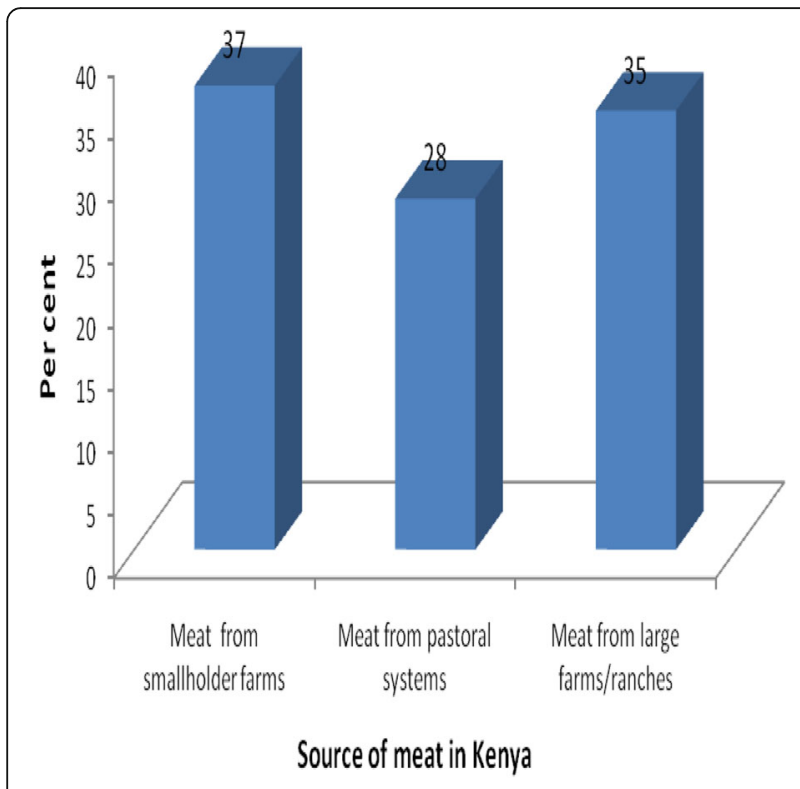

Fig. 3 The contribution of pastoralism to the national meat output

6.4\% from $12.5 \%$ reported by Nyariki (2004). Given the current total milk production, pastoral milk production stands at 1.05 billion litres annually from 0.6 billion reported in 2004, with pastoral cattle and camels producing annual quantities of 0.473 and 0.551 billion litres, respectively. Currently, the amount of camel milk is estimated at 0.551 billion litres valued at Kshs 16.5 billion (US $\$ 0.165$ billion). Similar findings have been reported by Behnke and Muthami (2011) and Kuria et al. (2016), who estimated the annual camel milk production at about 553 million litres. However, the estimate by the Government of Kenya (RoK 2010) is 200 million litres annually.

Nyariki (2004) established that the level of home consumption for an average pastoral household was $85 \%$ of the total milk produced while the remaining $15 \%$ was hawked in small townships and trading centres to supplement household income, especially during the wet season, or when forced sales occur due to urgent demands. As shown in Table 5, the milk from pastoral herds is worth Kshs 46.2 billion (US $\$ 0.462$ billion), a figure that is much higher than the Kshs 4.1 billion (US $\$ 0.041$ billion) estimate by Nyariki (2004). Moreover, the contribution of pastoral milk production to national production has increased to $18 \%$ compared to $10 \%$ as reported by Nyariki (2004) totalling to Kshs 39.27 billion (US\$0.3927) and Kshs 6.93 billion (US\$0.0693) worth of home-consumed and sold milk, respectively. The main reason for these differences is that prices for milk have more than quadrupled from Kshs 15/L (US\$0.15/ L) in 2004 to Kshs 60/L (US\$0.6/L) or higher in 2015 due to inflation and the rising cost of production and living. Besides, goat and sheep milk was not accounted for by Nyariki (2004) but has increasingly become an important source of protein to pastoral households when the cows are moved to dry season grazing areas. Further, due to increasing health conditions such as HIV/AIDS and diabetes, patients are being encouraged to consume camel and goat milk because of their high nutritive value.

\section{Non-traditional pastoral values \\ Pastoral honey and wax production}

Honey is one of the products from the pastoral areas in Kenya. According to the National Farmers Information Service (NAFIS), $80 \%$ of honey comes from the pastoral areas and specifically from the ASAL traditional log hives (http:// www.nafis.go.ke/livestock/beekeeping/). Kiptarus and Asiko (2014) and Honey Care Africa (2010) estimate annual honey production in Kenya at 100,000 metric tonnes valued at Kshs 4.3 billion (US $\$ 0.043$ billion). The pastoral region contributes 80,000 tonnes of honey valued at Kshs 3.44 billion (US $\$ 0.0344$ billion). From the national census carried out in 2009, Kenya had two million hives producing about 25,000 metric tonnes of honey (KNBS 2009), of which 20, 000 tonnes $(80 \%)$ came from the pastoral areas. However, in some cases, there are distinct sub-populations that are making honey but are not livestock-keeping, such as the Watta and Dorobo communities, although there are some that are both combined, as in the case of the Akamba community in Kitui and Machakos Counties of Kenya.

In terms of bee wax production, it is not documented how much comes from the pastoral areas. However, for this study, it was logical to adopt a similar percentage $(80 \%)$ to estimate the value of wax from the pastoral areas. Using this estimate, the national average annual beeswax estimate from 2010 to 2015 was US\$12.8 million or US $\$ 0.0128$

Table 5 Average amount (litres) and value (Kshs and US\$) of pastoral milk offtake in Kenya for the period 2010 to 2015; 1 US\$ is equivalent to Kshs 100

\begin{tabular}{lllll}
\hline Pastoral livestock species & Numbers/heads & Milk production in litres (bn) & Value in Kshs (billion) & Value in US\$ \\
\hline Cattle & $8,018,252$ & 0.473 & 28.385 & 0.28385 \\
Camel & $2,964,608$ & 0.551 & 16.542 & 0.16542 \\
Sheep & $9,747,340$ & 0.012 & 0.350 & 0.00350 \\
Goats & $12,928,424$ & 0.015 & 0.931 & 0.00931 \\
Total & & 1.05 & 46.208 & 0.46208 \\
\hline
\end{tabular}


Table 6 Beeswax gross production value in US\$(billion)

\begin{tabular}{lccccccc}
\hline Year & 2010 & 2011 & 2012 & 2013 & 2014 & $2015^{*}$ & Average \\
\hline Gross production value & 0.7 & 0.67 & 0.65 & 1.46 & 2.27 & 1.90 & 1.28 \\
\hline
\end{tabular}

*2015: figures are projections

billion or Kshs 1.28 billion (at an exchange rate of Kshs 100/US\$) (Table 6).

\section{Tourism}

Pastoralism plays a number of roles in supporting the tourism industry. It promotes peaceful co-existence with wildlife and ensures land is conserved in its natural state, making the land suitable for wildlife, a major tourist attraction in the pastoral land (Nyariki et al. 2009). Kenya has 54 parks and reserves, about $60 \%$ of which are found in the pastoral areas. However, the revenues from the parks and reserves have continued to decline from Kshs 7.7 billion (US $\$ 0.077$ billion) in 2011 to Kshs 1.25 billion (US\$0.0125 billion) in 2013 as a result of terrorism threats and attacks (Table 7). In an effort to build confidence in the tourism sector, the Government of Kenya launched a national tourism recovery marketing strategy through campaigns, promotions and Tembea Kenya Initiative that has seen the rise in the number of visitors and revenues in the parks and reserves from Kshs 1.25 billion (US\$0.0125 billion) in 2013 to Kshs 2.34 billion (US\$0.0234 billion) in 2015.

The World Travel and Tourism Council (WTTC) 'Economic Impact 2017 Kenya' estimates the direct contribution of tourism and travel sector to GDP at \$2.5 billion (3.7\%) in 2016. In addition, it directly employed 399,000 Kenyans or $3.4 \%$ of the total workforce that year https:// www.oxfordbusinessgroup.com/overview/back-track-afterperiod-decline-tourism-sees-its-fortunes-rise/. The value of tourism in the pastoral landscape of Kenya, as an indirect contribution by pastoralism, was estimated through park entry fees by the national and foreign residents as reported in the Statistical Abstract (2016). Similar approaches have been used by Ericksen et al. (2011), Silvestri et al. (2013) and King-Okumu et al. (2016). In Kenya, the value of tourism in the pastoral areas is estimated at Kshs 2.91 billion (US\$0.0291 billion) (Table 7). This value includes the cost of accommodation in hotels, and park and reserve entry fees. The revenue posted by Amboseli National Park in the year 2011 was exceptionally high and outside the expected range even though the park is increasingly becoming a park of choice and the second most preferred by tourists after Masai Mara. Therefore, no particular explanation could be given since the data for these calculations were all obtained from a similar source, the Government of Kenya Statistical Abstracts (2016).

\section{Value of fishing in the pastoral areas of Kenya}

Fish is an emerging product in the pastoral areas and quite often has not been taken as an important resource in pastoralism. With increasing impacts of climate change, especially drought conditions, pastoralists have accepted fish as an important resource for enhancing resilience. Fishing is growing rapidly in the pastoral areas, especially from rivers, natural lakes and other artificial aquaculture systems such as ponds. However, this study only considers the value of fish obtained from natural water bodies such as rivers and lakes (Table 8).

The average annual value of fish from the pastoral areas was estimated at Kshs 1.65 billion (US\$0.0165

Table 7 Kenya pastoral parks and reserves revenue in US\$ (billion); I US\$ is equivalent to Kshs 100

\begin{tabular}{|c|c|c|c|c|c|c|c|}
\hline \multirow[t]{2}{*}{ Conservation area } & \multicolumn{7}{|c|}{ Annual value in US\$ (billion) } \\
\hline & 2011 & 2012 & 2013 & 2014 & 2015 & Total & Average \\
\hline Amboseli National Park & 0.0540 & 0.0006 & 0.0006 & 0.0050 & 0.0030 & 0.0632 & 0.0126 \\
\hline Tsavo West National Park & 0.0030 & 0.0020 & 0.0020 & 0.0010 & 0.0008 & 0.0088 & 0.0018 \\
\hline Tsavo East National Park & 0.0080 & 0.0050 & 0.0040 & 0.0030 & 0.0020 & 0.0220 & 0.0044 \\
\hline Maasai Mara National Reserve & 0.0050 & 0.0040 & 0.0040 & 0.0070 & 0.0060 & 0.0260 & 0.0052 \\
\hline Hallers Park & 0.0001 & 0.0002 & 0.0002 & 0.0002 & 0.0070 & 0.0077 & 0.0015 \\
\hline Meru National Park & 0.0003 & 0.0002 & 0.0002 & 0.0006 & 0.0005 & 0.0018 & 0.0004 \\
\hline Samburu & 0.0005 & 0.0006 & 0.00002 & 0.0007 & 0.0003 & 0.0021 & 0.0004 \\
\hline Kisite Marine & 0.0004 & 0.0004 & 0.0005 & 0.0002 & 0.0002 & 0.0017 & 0.0003 \\
\hline Watamu Marine & 0.005 & 0.0003 & 0.0003 & 0.0003 & 0.003 & 0.0089 & 0.0018 \\
\hline Others* & 0.0007 & 0.0006 & 0.0007 & 0.0006 & 0.0006 & 0.0032 & 0.0006 \\
\hline Total & 0.0770 & 0.0139 & 0.01252 & 0.0186 & 0.0234 & 0.1454 & 0.0291 \\
\hline
\end{tabular}

*Others include Marsabit, Sibiloi, Chyulu, Ruma National Park, Mwea National Reserve and Kiunga Source: KNBS (2016) 
Table 8 Pastoral fish production in metric tonnes and value to fishermen in US\$ (million); 1 US\$ is equivalent to Kshs 100

\begin{tabular}{|c|c|c|c|c|c|c|c|c|c|c|}
\hline \multirow[t]{2}{*}{ Type of fish } & \multicolumn{2}{|l|}{2011} & \multicolumn{2}{|l|}{2012} & \multicolumn{2}{|l|}{2013} & \multicolumn{2}{|l|}{2014} & \multicolumn{2}{|l|}{2015} \\
\hline & $\begin{array}{l}\text { Production } \\
\text { (metric tonnes }\end{array}$ & US\$ & $\begin{array}{l}\text { Production } \\
\text { (metric tonnes) }\end{array}$ & US\$ & $\begin{array}{l}\text { Production } \\
\text { (metric tonnes) }\end{array}$ & US\$ & $\begin{array}{l}\text { Production } \\
\text { (metric tonnes) }\end{array}$ & US\$ & $\begin{array}{l}\text { Production } \\
\text { (metric tonnes) }\end{array}$ & US\$ \\
\hline Fresh water fish & 9093 & 4.41 & 4403 & 4.34 & 5684 & 5.73 & 5769 & 6.59 & 5730 & 6.53 \\
\hline Marine water fish & 6722 & 5.27 & 6584 & 7.22 & 6774 & 7.74 & 6876 & 8.68 & 6354 & 8.53 \\
\hline Crustaceans & 404 & 1.20 & 509 & 1.91 & 576 & 2.33 & 391 & 1.90 & 537 & 1.94 \\
\hline Molluscs & 538 & 0.55 & 587 & 0.89 & 608 & 0.84 & 587 & 1.14 & 900 & 4.50 \\
\hline Total & 16,757 & 11.43 & 12,083 & 14.36 & 13,642 & 16.64 & 13,623 & 18.31 & 13,521 & 21.50 \\
\hline
\end{tabular}

Source: KNBS (2016)

billion) with a minimum of Kshs 1.143 billion (US\$0.01143 billion) in 2011 to a maximum of Kshs 2.15 billion (US\$0.0215 billion) in 2015. These figures exclude the value of fish through aquaculture and fish farming. The contribution of ASAL fish production to total national fish production is between 8 and $11 \%$ (Table 9).

\section{Computed total economic value of pastoralism}

The total computed economic value of pastoral systems in Kenya is shown in Table 10. Live animals as a capital resource for pastoral production and a key component of the pastoral system were valued at Kshs 233.7 billion (US\$2.337 billion). The value of traditional pastoralism is estimated at Kshs 103.8 billion (US\$1.038 billion) and constitutes 91.85\% of the pastoral economic worth. Overall, milk constitutes $40.88 \%$, followed by meat at about $34.25 \%$ of the pastoral worth, followed by non-traditional pastoral products such as honey and wax which have also begun to make a noticeable contribution to the pastoral economy, accounting for $8.15 \%$ of the pastoral value.

\section{Uncomputed (indirect) values of pastoral economy Provision of draft power and transport}

Pastoral livestock provides traction and transport within the pastoral production system and as a service to other producers (e.g. cultivators). The value of transportation, particularly of goods to and from the market, but also of the sick to hospital, is difficult to quantify or monetise realistically. There is need therefore for more data to understand the extent of transportation and its contribution to pastoral economies.

\section{Risk and diversification management}

The pastoral communities derive several benefits from livestock-keeping, including the provision of credit, insurance, and as a means of sharing risk. The credit benefits of livestock derive from the ability of livestock owners to 'cash in' their animals for particular purposes at a time they choose. Unfortunately, the benefits could not be quantified and valued in this study.

\section{Socio-cultural values of pastoralism}

Another un-computed value because of data challenges is that of livestock as a source of bride price and a measure of wealth and social status for pastoralists and agropastoralists. Livestock has value as a source of manure and traction and as an investment that is converted into cash to purchase food or is directly exchanged for food or slaughtered for the same. Also, livestock provides employment and income to the country's population. For example, in Ethiopia, the Borana accumulate animals as social and economic assets rather than as a source of income (Coppock 1994; Bekure et al. 1991). In this way, they also protect themselves from perturbations which are part and parcel of pastoral production (Nyariki 2004; King-Okumu et al. 2016).

\section{Household nutrition security}

Pastoralism plays a significant contribution to household nutrition directly through the provision of protein as essential elements for human diet or indirectly through the sale of livestock products to purchase other essential elements in the human diet such as cereals and minerals. The livestock products include

Table 9 Contribution of ASAL fish to the national fish production in metric tonnes

\begin{tabular}{llllll}
\hline Regions & 2011 & 2012 & 2013 & 2014 & 2015 \\
\hline ASAL & $16,757(11)$ & $12,083(8)$ & $13,645(8)$ & $13,623(8)$ & $13,521(9)$ \\
Non-ASAL & $132,289(89)$ & $141,932(92)$ & $149,744(92)$ & $154,790(92)$ & $130,816(91)$ \\
Total & $149,046(100)$ & $154,015(100)$ & $163,389(100)$ & $168,413(100)$ & $144,337(100)$ \\
\hline
\end{tabular}

Figures in parentheses are percentages 
Table 10 Overall computed total economic value of pastoralism in Kenya (US\$) billion

\begin{tabular}{lll}
\hline Pastoral products & Value in US\$ (billion) & Proportion of total value (\%) \\
\hline \multicolumn{2}{l}{ Traditional pastoral products } \\
Livestock offtake & 0.1890 & 16.72 \\
Meat (kg) & 0.3870 & 34.25 \\
Milk & 0.4620 & 40.88 \\
Sub-total & 1.038 & 91.85 \\
Non-traditional pastoral products & \\
Honey & 0.0344 & 3.04 \\
Wax & 0.0103 & 0.91 \\
Tourism & 0.0291 & 2.57 \\
Fish & 0.0165 & 1.46 \\
Sub-total & 0.0903 & 8.15 \\
Total & 1.1283 & 100.00 \\
\hline
\end{tabular}

milk, meat and blood. The national average protein supply for Kenya is between 58 and $61 \mathrm{~g} /$ capita/day.

\section{Source of employment}

In the arid and semi-arid areas, the livestock sector accounts for $90 \%$ of employment and more than $95 \%$ of household incomes, and it is challenging to attach a monetary value to this. Pastoralism provides direct employment to about 2.2 million people in Kenya (Nyariki, 2017). Indirect employment that is difficult to quantify is in ranching, trade in livestock, transport services, leather industry, slaughterhouses, butcheries and eating houses. A huge proportion of people employed in these areas depend to a large extent on pastoral livestock (Nyariki, 2017).

\section{Pastoralism as an input for agriculture}

The sale of manure is gaining momentum in the pastoral areas. As prolonged drought is making it hard to find pasture and food, many households in the pastoral areas are selling manure to help them buy food and pay hospital bills. Using manure for farming helps store carbon in the soil and prevents it from being released into the atmosphere, and in this way, communities contribute to reducing climate-changing emissions. According to Thomson Reuters Foundation (2017), in Kajiado, Kenya, from a 40 head of cattle herd, a farmer collects 8 tonnes of manure every month, which is sold at Kshs 36,000 (US\$360) and is used to fertilise 1.5 acres $(0.6 \mathrm{ha})$ of tea plantation in central Kenya. A tea plant normally yields about 1.5 $\mathrm{kg}$ of leaves a year, but when enriched with manure, it can produce as much as $3 \mathrm{~kg}$. Therefore, application of manure increases tea production by $100 \%$. At present, manure is estimated to contribute about $7.54 \%$ (Kshs 27.829 billion or US\$0.27829 billion) of the gross value of livestock. Even though the sale of manure in the pastoral areas is gaining momentum, it is likely to influence the self-fertilisation and productivity of pastures due to the random distribution of manure.

\section{Conclusion}

As this study has demonstrated, pastoralism contributes immensely to the Kenyan economy through traditional and non-traditional pastoral values. The nontraditional pastoral activities are increasingly contributing to the pastoral livelihoods; namely honey, gum resin, firewood, fishing and tourism. However, the traditional values such as livestock and its related products still account for the greatest percentage of the pastoral economic worth. The application of TEV is useful as a tool for computing the true economic worth of pastoralism. The demonstration of a more robust estimate of the total value of pastoralism can be used as a lobbying mechanism to position the production system high in the national development agenda.

\section{Recommendation}

There is a need for future research to explore how to use TEV to compute the uncomputed values of pastoralism-draft power, household nutrition, input for agriculture and livestock dung (as fuel and raw material for the agricultural industry), carbon sequestration and other purposes. There is also a need to gather relevant data to help analyse the trends in the total economic value of pastoralism over time.

\section{Acknowledgements}

The authors recognise the contribution of three field assistants who participated in the data collection; the Wildlife Service Research Department in Amboseli; and Loitokitok Sub-county Agriculture, Livestock and Veterinary Officers for availing secondary data and identifying the champions and institutions to be contacted for the study. We are grateful to Charles Ikutwa, University of Nairobi, for providing technical and logistical support for the data collection and analysis. This study was funded by the Intergovernmental Authority on Development (IGAD).

\section{Authors' contributions}

NDM was the principal investigator. He supported the design and coordination of this research. He also participated in the field work including data collection, focus group discussions, data analysis, presentation, discussions and writing of this paper. ADA was in charge of organising the research logistics including daily planning of activities as per the work plan and budget. She also contributed to the literature review and field work including data collection, focus group discussions, data analysis, presentation, discussions and writing of this paper. Both authors read and approved the final manuscript.

\section{Authors' information}

Prof. Dickson Mong'are Nyariki has BSc, MSc (University of Nairobi, Kenya) and PhD (University of Reading, UK) degrees. Prof Nyariki specialised in Agricultural Economics with a bias towards dryland resources and food security. He is currently a Prof of Agricultural Economics, School of Business and Economics; and a Vice Chancellor of Murang'a University of Technology. He has carried out numerous consultancies and research on drylands and published more than 100 journal articles, book chapters, books and refereed conference proceedings. Prof. Nyariki has coordinated regional projects on food security, livestock production, pastoralism and water harvesting. He has 
taught at various universities for more than 30 years and supervised more than 40 postgraduate projects.

Dr. Dorothy Akinyi Amwata has BSc, MSc and PhD (University of Nairobi, Kenya) degrees. Dr. Amwata is a Rangeland Eco-Sociologist and Senior Lecturer, Department of Agricultural Sciences, South Eastern Kenya University, and an Adjunct Faculty Member, School of Hospitality and Tourism, Murang'a University of Technology. She has specialised in dryland/rangeland management, ecosystem assessments, agriculture and food security, rangeland and natural resource management and policy, and ecosystem monitoring and evaluation. She has carried out research and worked for close to two decades on climate change, conservation of biodiversity, land degradation, climate adaptation, resilience and mitigation, monitoring and evaluation of projects, project appraisal, and planning, management and implementation.

\section{Funding}

This research was made possible through USD 20,000 competitive research funding from the Intergovernmental Authority on Development (IGAD), Nairobi Office, Kenya.

\section{Availability of data and materials}

The data and materials used in this research are available in Microsoft Excel, and the data is available for sharing.

\section{Competing interests}

The authors declare that they have no competing interests.

\section{Author details}

${ }^{1}$ School of Business and Economics, Murang'a University of Technology, P.O. Box 75-10200, Murang'a, Kenya. 'Department of Agricultural Sciences, South Eastern Kenya University, P.O. Box 170-90200, Kitui, Kenya. ${ }^{3}$ School of Hospitality and Tourism, Murang'a Unversity of Technology, P.O.Box 75-10200, Murang'a, Kenya.

Received: 24 April 2018 Accepted: 22 May 2019

Published online: 17 July 2019

\section{References}

Amwata, D.A., D.M. Nyariki, and N.R.K. Musimba. 2015. Factors influencing agropastoral and pastoral households' vulnerability to food insecurity in the drylands of Kenya: A case study of Kajiado and Makueni Counties. Journal of International Development. https://doi.org/10.1002/jid.3123.

Barbier, E.B., N. Acreman, and D. Knowler. 1997. Economic valuation of wetlands. A guide for policy makers and planners. Gland: RAMSAR Convention Bureau.

Behnke, R., and D. Muthami. 2011. The contribution of livestock to the Kenyan economy (IGAD LPI working paper no. 03-11). Djibouti: IGAD Centre for Pastoral Areas and Livestock Development (ICPALD).

Bekure, S., P.N. de Leeuw, and R. Nyambaka. 1991. The long-term productivity of the Maasai livestock production system. In Maasai herding: An analysis of the livestock production system of Maasai pastoralists in eastern Kajiado District, Kenya, ed. S. Bekure, P.N. de Leeuw, B.E. Grandin, and PJ.H. Neate. Addis Ababa: ILCA Systems Study 4.

Coppock, L.D. 1994. The Borana Plateau of southern Ethiopia: synthesis of pastoral research, development and change, 1980-91. Nairobi: Addis Ababa, International Livestock Centre for Africa (ILCA).

Davis, J. 2006. Total economic valuation of Kenyan pastoralism. Nairobi: International Union for Conservation of Nature (IUCN).

Ericksen, P.J., M.Y. Said, J. de Leeuw, S. Silvestri, L. Zaibet, S.C. Kifugo, K. Sijmons, J. Kinoti, L. Ng'ang'a, F. Landsberg, and M. Stickler. 2011. Mapping and valuing ecosystem services in the Ewaso Ng'iro watershed. Nairobi: ILRI.

Food and Agriculture Organisation (2014). FAOSTAT data. Rome, Italy.

Fitzgibbon, C. 2012. Economics of resilience study - Kenya country report. https://www.gov.uk/government/TEERR_Kenya_Background_Report.pdf/.

GoK. 2012. Arid and Semi-arid Land Policy. Minister of State for Development of Northern Kenya and Other Arid Lands, Nairobi, Kenya.

Hatfield, R., and J. Davis. 2006. Global review of the economics of pastoralism. Nairobi: IUCN.

Hesse, C, J MacGregor. 2006. Pastoralism: drylands' invisible asset? Pastoral Civil Society in East Africa, IIED Issue Paper No. 142.

Honey Care Africa.2010. Honey value chain in Kenya. https://www. businesscalltoaction.org/member/honey-care-africa/

ILRI (International Livestock Research Institute). 2013. News on better lives through livestock. https://www.ilri.org/ilrinews/index.php/archives/category/ilri/ple/
Intergovernmental Authority on Development (IGAD). 2017. Resilience context analysis. Resilience to shocks that impact food security and nutrition in Kenya. Nairobi: IGAD.

IRIN (Integrated Regional Information Networks). 2013. Pastoralism's economic contributions are significant but overlooked. http://www.irinnews.org/report/ 98052/pastoralism-economic-contributions-are-significant-overlooked. downloaded. 8 May 2017.

Karaimu, P. 2013. Making visible the 'invisible benefits' of African pastoralism will spur national and pastoral economies both. https:/clippings.lli.org/2013/06/24/ making-visible-the-invisible-benefits-of-african-downloaded. 10 Nov 2018.

King-Okumu, C., V.O. Wasonga, I. Jarso, and Y.M.S. Salah. 2016. Direct use values of climate dependent ecosystem services in Isiolo County. London: IIED.

Kiptarus, J., and G. Asiko. 2014. Kenya country report. In Presentation to Apitrade, Zimbabwe.

Krätli, S. 2015. Valuing Variability: New Perspectives on Climate Resilient Drylands Development. London: IIED 2015.

KNBS. 2009. 2009 population census. Nairobi: Kenya National Bureau of Statistics.

KNBS (Kenya Bureau of National Statititics). 2016. Statistical Abstract 2016. Herufi House, Ministry of planning and Development, Nairobi, Kenya. ISBN 9966767-57-6.

Kuria, S.G., O.K. Koech, A.O. Adongo, S. Murithi, J.T. Njoka, and P. Kamande. 2016. Cost of production, marketing and revenue generation from somali camel breed in Isiolo and Marsabit counties of northern Kenya. Livestock Research for Rural Development 28: 12.

Letara, J., J. MacGregor, and C. Hesse. 2006. Estimating the economic significance of pastoralism: The example of the nyama choma sector in Tanzania; Pastoral Civil Society in East Africa.

Mbuza, M.B.F., D. Ngambeki, and E.N. Sabiiti. 2014. Role of credit in the uptake and productivity of improved dairy technologies in Uganda.

Mdoe, N., and R. Mnenwa. 2007. Study on options for pastoralists to secure their livelihoods: Assessing the total economic value of pastoralists in Tanzania. Tanzania: TNRF.

Muhereza, F.E., and S.A. Ossiya. 2004. Pastoralism in Uganda, people, environment and livestock: Challenges for the PEAP. Kampala: Uganda National NGO Forum and Civil Society Pastoral Task Force.

Mwanyumba, P.M., R.W. Wahome, L. MacOpiyo, and P. Kanyari. 2015. Livestock herd structures and dynamics in Garissa County, Kenya. Pastoralism 5: 26. https://doi.org/10.1186/s13570-015-0045-6/.

Nyariki, DM. 2004. The contribution of pastoralism to the local and national economies in Kenya. Unpublished report, April 2004. RECONCILE/IIED.

Nyariki, D.M. 2009. Price response of herd off-take under market liberalization in a developing cattle sector: Panel analysis applied to Kenya's ranching. Environment and Development Economics 14 (2): 263-280.

Nyariki, D.M., and K. Munei. 1993. Economic factors affecting the level of beef production from ranching: an example of Kenya's cattle sector. East African Agricultural and Forestry Journal 59 (2): 163-170.

Nyariki, D.M., A.W. Mwang'ombe, and D.M. Thompson. 2009. Land use change and livestock production challenges in an integrated system: the Maasai Mara Ecosystem, Kenya. Journal of Human Ecology 26 (3): 163-173.

Nyariki, D.M., and R.K. Ngugi. 2002. A review of African pastoral production system: Approaches to their understanding and development. Journal of Human Ecology 13 (3): 137-250.

Nyariki, D.M. 2017. Assessment of the economic valuation of pastoralism in Kenya. A report for IGAD, Nairobi, Kenya.

Odhiambo, M. 2006. Review of the literature on Pastoral Economics and Marketing: Kenya, Tanzania, Uganda and the Sudan. In Report prepared for the World Initiative for Sustainable Pastoralism, IUCN EARO, RECONCILE, Nairobi, Kenya.

Otte, M.J., and P. Chilonda. 2012. Cattle and small ruminant production systems in sub-Sahara Africa. A systems review. Rome: Food and Agriculture Organisation.

Peden, D., G. Tadesse, and M. Mammo. 2002. Improving the water productivity of livestock. An opportunity for poverty reduction. Addis Ababa: ILRI.

Republic of Kenya (RoK). 2016. Statistical abstracts. Nairobi: Ministry of Finance Planning and Development.

RoK. 2010. 2009 Kenya population and housing census vol. II. Nairobi: Population and Household Distribution by Socioeconomic Characteristics.

RoK (Republic of Kenya). 2000. Livestock marketing from pastoral areas in Kenya: A strategy for pastoral development. A Report by Arid Lands Resources Management Project (ALRMP) in conjunction with SNV, OXFAM and World Concern. Office of the President, Nairobi.

Shanahan, M. 2013. Media perceptions and portrayals of pastoralists in Kenya, India and China. United Kingdom: UK Aid.

Silvestri, S., L. Zaibet, M.Y. Said, and S.C. Kifugo. 2013. Valuing ecosystem services for conservation and development purposes: a case study from Kenya. Environmental Science and Policy 31: 23-33. 
Thomson Reuters Foundation. 2017. Drought-hit Maasai herders using manure to fight hunger. http://databank.worldbank.org/data/databases.aspx/. 4 July 2017.

UNECA (United Nations Economic Commission for Africa). 2016. Expert group meeting on New Fringe Pastoralism (NFP) development, conflict and insecurity in the Horn of Africa and the Sahel. 25-27 Aug 2016. http:// databank.worldbank.org/data/databases.aspx/.

Wakhungu, J., J. Wesongah, G. Tura, G. Msalya, D. Grace, F. Unger, and S. Alonso. 2014. Pastoralism in Kenya and Tanzania: Challenges and opportunities in animal health and food security. In Poster prepared for the 6th all Africa Conference on Animal Agriculture. Nairobi: ILRI www.slideshare.net/ILRI/ pastoralism-kenya-tanzania.

World Bank.2017. World Bank data bank. http://databank.worldbank.org/data/ databases.aspx

Zaal, A.F.M. 1998. Pastoralism in a global age: livestock marketing and pastoral commercial activities in Kenya and Burkina Faso, 307 CABI, ISBN: 9055380369.

\section{Publisher's Note}

Springer Nature remains neutral with regard to jurisdictional claims in published maps and institutional affiliations.

\section{Submit your manuscript to a SpringerOpen ${ }^{\circ}$ journal and benefit from:}

- Convenient online submission

- Rigorous peer review

- Open access: articles freely available online

- High visibility within the field

- Retaining the copyright to your article

Submit your next manuscript at $\boldsymbol{\nabla}$ springeropen.com 